\title{
Deep Brain Stimulation as a Treatment Approach for Anorexia Nervosa: a Systematic Literature Review
}

\section{Estimulação cerebral profunda como uma abordagem de tratamento para anorexia nervosa: Uma revisão sistemática de literatura}

\author{
Ledismar José da Silva ${ }^{10}$ Tâmara Husein Naciff ${ }^{1} \quad$ Maria Flávia Vaz de Oliveira $^{1}$ \\ ${ }^{1}$ Department of Medicine, Pontifícia Universidade Católica de Goiás, \\ Goiânia, GO, Brazil \\ Arq Bras Neurocir 2019;38:175-182. \\ Address for correspondence Ledismar José da Silva, Departmento \\ ode Medicina, Pontifícia Universidade Católica do Rio de Janeiro, Rua \\ 235, 76 - Setor Leste Universitário, Goiânia, GO, 74175-120, Brazil \\ (e-mail: ledismarsilva@gmail.com).
}

\begin{abstract}
Keywords

- anorexia nervosa

- eating disorder

- deep brain stimulation

- neuromodulation
\end{abstract}

\section{Resumo \\ Palavras-chave \\ - anorexia nervosa \\ - desordem alimentar \\ - estimulação cerebral profunda \\ - neuromodulação}

Anorexia nervosa is a psychiatric disorder characterized by distortions of body size, weight, and shape perception, as well as by food restriction and/or binge and purging behaviors. It mostly affects young women and causes severe negative impacts on their physical, psychological, and social health. Recent studies have analyzed deep brain stimulation (DBS), a neurosurgical procedure that involves electrode implantation in strategical brain areas, to obtain remission of the symptoms of anorexia nervosa. The results showed that the stimulation of areas associated to the neurocircuitry of anorexia nervosa, such as nucleus accumbens, anterior cingulate cortex, ventral striatum, and bed nucleus of the stria terminalis, provokes beneficial responses in terms of body mass index, quality of life, social functioning, and psychiatric comorbidities. Nevertheless, broader investigations are needed to endorse the clinical usage of DBS in the management of anorexia nervosa.

A anorexia nervosa é uma desordem psiquiátrica caracterizada pela distorção da percepção de tamanho, peso e formas corporais, bem como por restrição alimentar e/ou comportamentos excessivos e purgativos. Afeta principalmente mulheres jovens e causa grande impacto negativo sobre a sua saúde física, psicológica e social. Estudos recentes analisaram a estimulação cerebral profunda (ECP), um procedimento neurocirúrgico que envolve a implantação de eletrodos em áreas cerebrais estratégicas, como forma de obter remissão dos sintomas da anorexia nervosa. Os resultados demonstraram que a estimulação de regiões que participam da neurocircuitaria da anorexia nervosa, como núcleo accumbens, córtex do cíngulo anterior, estriato e núcleo da estria terminal, provocou respostas benéficas em termos de índice de massa corporal, qualidade de vida, funcionamento social e comorbidades psiquiátricas. No entanto, investigações mais amplas são necessárias para se recomendar a aplicação clínica da ECP no manejo da anorexia nervosa.

(1) Ledismar José da Silva's ORCID is https://orcid.org/0000-0002-35512650.

received

November 1, 2018

accepted

February 19, 2019
DOI https://doi.org/

10.1055/s-0039-1685486. ISSN 0103-5355.
Copyright $\odot 2019$ by Thieme Revinter

Publicações Ltda, Rio de Janeiro, Brazil
License terms

(c) $(1) \$$ 


\section{Introduction}

Anorexia nervosa is a debilitating and challenging condition with the highest mortality rate among all the psychiatric disorders, ranging from 6 to $11 \% .^{1,2}$ It is characterized by intense fear of putting on weight, persistent and severe restriction of food intake, adoption of behaviors that interfere with weight gain, and disturbed perception of the body weight, size, and shape. . $^{2,3}$

The disorder affects $0.7 \%$ of the world population, mainly women (ratio of male to female $=10: 1$ ), and, among them, especially teenage girls. The age at onset of anorexia nervosa ranges from 15 to 19 years old in $40 \%$ of the cases. ${ }^{2}$

The etiology of anorexia nervosa is complex and multifactorial. Genetic predisposition and personality traits play important roles on the genesis and perpetuation of the disease. Additionally, environmental features such as cultural pressure for thinness and standardized beauty models may trigger the disorder. ${ }^{4}$

It is widely known that anorexia nervosa can have profound effects on people's health. One of the main consequences of the disease, chronic malnutrition, may lead to severe physical complications, including hydroelectrolytic, gastrointestinal, hepatic, and cardiac disorders, and bone lesions. ${ }^{5,6}$ Furthermore, other psychiatric disorders, such as major depression, generalized anxiety, obsessive compulsive disorder (OCD), and personality disorders, often accompany anorexia nervosa. ${ }^{7}$ Also, anorexic patients have a higher risk of eventually becoming addicted to alcohol and drugs. ${ }^{8}$

In spite of all these impairments caused by anorexia nervosa, the evidences that demonstrate the efficacy of the current therapies to treat this disorder are weak. ${ }^{9,10}$ So far, conventional therapeutic approaches have failed to elicit disease remission in nearly $50 \%$ of the patients. ${ }^{11}$

Deep brain stimulation (DBS) is a neurosurgical procedure that has been used for almost 30 years to adjust the activity of dysfunctional brain circuits. It exerts effects not only locally, but also on distant targets, through mono and polysynaptic connections. The DBS technique is considered safe and effective for the treatment of Parkinson's disease and essential tremor. Its use has also been recently extended to some psychiatric disorders, such as major depression, OCD, Tourette syndrome, and Alzheimer disease. ${ }^{2}$

Currently, DBS has been explored as a novel treatment modality for anorexia nervosa. Several studies have shown the use of DBS for the treatment of anorexic patients in experimental trials with promising results. ${ }^{2,12}$

This study aimed to perform a systematic review of the literature to identify and discuss the indications, outcomes, and side effects of DBS as a treatment approach for patients with anorexia nervosa.

\section{Methods}

A systematic literature review was performed aiming to identify the use of DBS for the treatment of people with anorexia nervosa. The search was performed by two independent researchers and followed the steps proposed in the
Preferred Reporting Items for Systematic Reviews and MetaAnalyses (PRISMA) protocol. ${ }^{13}$

The databases searched for this study were: Medical Literature, Analysis, and Retrieval System Online (MEDLINE), Cochrane Central Register of Controlled Trials (CENTRAL), Latin American and Caribbean Health Sciences Literature (LILACS), Web of Science, Cumulative Index to Nursing and Allied Health Literature (CINAHL), Health Technology Assessment (HTA), PsycINFO, The Digital Library of Theses and Dissertations of the Universidade de São Paulo (Digital Library USP), Portal de Periódicos da Coordenação de Aperfeiçoamento de Pessoal de Nível Superior do Ministério da Educação (CAPES/MEC), Instituto Brasileiro de Informação em Ciência e Tecnologia (IBICT), ProQuest Dissertations \& Theses (PQDT) Global, ClinicalTrials.gov, Registro Brasileiro de Ensaios Clínicos (ReBec), World Health Organization International Clinical Trials Registry Platform (WHO ICTRP), International Standard Randomized Controlled Trials Number (ISRCTN), Australian New Zealand Clinical Trials Registry (ANZCTR), and Deutschen Register Klinischer Studien (DRKS).

The descriptors selected around Boolean operators were: anorexia, $\mathrm{OR}$ anorexia nervosa, $\mathrm{OR}$ "eating disorder, OR binge eating, AND deep brain stimulation, OR DBS, OR neurofunctional surgery, OR electrode implantation, OR neurostimulation, OR neuromodulation, OR psychiatric surgery, and their equivalents in Portuguese, Spanish, German, and French. The terms were searched in all fields of the databases.

The following inclusion criteria were applied for the selection of the studies: 1 . articles correlating anorexia nervosa and DBS as a treatment strategy; 2. articles published from 2008 to 2018; 3. articles in English, Portuguese, Spanish, German, and French; 4. articles involving human experimental studies, case reports, and review studies.

The exclusion criteria selected for this review were: 1 . duplicate articles; 2 . studies involving animal experimentation; 3. articles involving the philosophical and existential implications of DBS. Along the search process in the databases, the keywords deep brain stimulation = ; DBS; neurofunctional surgery; electrode implantation; neurostimulation; neuromodulation and psychiatric surgery have resulted in a considerable amount of studies whose main purpose was to approach existential, ethical and philosophical limitations of the DBS procedure. However, often in the search results, these studies have shown to escape the scope of the present review and were, therefore, excluded; 4. editorials, authors' comments, or debates; 5 . articles addressing any psychiatric disorders other than anorexia nervosa; 6 . articles reporting any neurosurgical interventions other than DBS.

The data obtained during this systematic literature review are shown in - Fig. 1.

A total of 74 finished studies were used to perform the review. Nevertheless, we described in the results section only the eight existent experimental studies that applied DBS on patients with anorexia nervosa. The remaining 66 studies were used to compose others sections of this paper, such as introduction, discussion and conclusion, once they were constituted by reviews studies and represent a compilation of the data obtained on the experimental studies. 


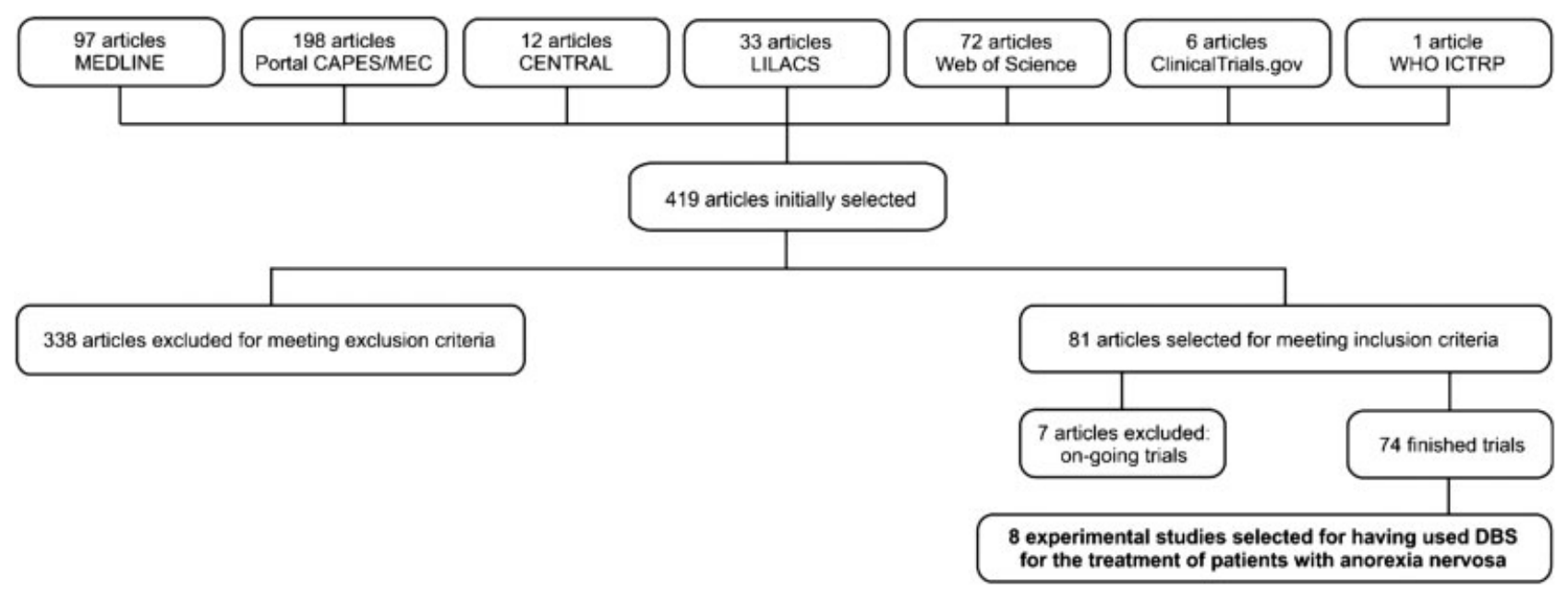

Fig. 1 Data obtained during this systematic literature review

\section{Results}

In this systematic literature review, eight experimental studies were selected for having used DBS for the treatment of patients with anorexia nervosa. Nucleus accumbens (NAc) plays a central role in the reward circuitry. Therefore, it has been used as a target in several studies that aimed to apply a neurosurgical treatment to anorexia nervosa. ${ }^{1-3}$

Bilateral NAc DBS (stimulation frequency: $180 \mathrm{~Hz}$; pulse width: $90 \mu \mathrm{s}$; stimulation voltage: $1-8 \mathrm{~V}$ ) was performed in 4 female teenagers diagnosed with anorexia nervosa, refractory to conventional treatment. Before surgery, the mean age of the patients was 16.5 years, and the average duration of this disorder was 18.5 months. At the beginning of the study, all the patients had some psychiatric comorbidities, and none of them was attending school due to physical or psychiatric limitations. The patients underwent this neurosurgical procedure between 2007 and 2011, with a mean follow-up period of 38 months (9-50 months) after the surgery. A considerable improvement was observed in the medical conditions of the patients. Their average body mass index (BMI) increased from $11.9 \mathrm{~kg} / \mathrm{m}^{2}$ at baseline to $19.6 \mathrm{~kg} / \mathrm{m}^{2}$ at the last follow-up, that is, a $65 \%$ increase, no longer meeting the diagnostic criteria for anorexia nervosa. ${ }^{1}$ Their menstrual cycles became regular in an average period of 6.8 months after the surgery, and the symptoms and comorbidities had a decrease. The average score in the Yale-Brown ObsessiveCompulsive Scale (Y-BOCS) reduced from 29 to 1.7 and so did the average score in the Hamilton Rating Scale for Anxiety (HAMA), decreasing from 19 to 2 . At the end of the study, three out of the four patients returned to school. ${ }^{14}$

Similar results were found in an independent study that involved eight women with anorexia nervosa, six of whom underwent bilateral stereotactic radiofrequency ablation, and two, bilateral DBS (135-185 Hz; 120-210 $\mu \mathrm{s} ; 2.5-3.8 \mathrm{~V}$ ), both procedures having NAc as the target area. At baseline, the vital signs of the patients, such as blood pressure, heart rate, and temperature, were low; after the interventions, all of them increased and became normal 1 year after the surgery. The BMI significantly increased $(p<0.001) 6$ months and 1 year after the procedures. The mean BMI of the patients did not reach the normal range, but it came close to its inferior value of normality. The menstrual cycle became normal in all the patients in a mean period of 4.63 months. ${ }^{15}$

In both studies, a significant increase regarding intelligence, memory, quality of life, and social functioning, and a significant decrease in nervosity, psychoticism, and tendency to lie were noted. Yale-Brown obsessive-compulsive scale, HAMA, and Hamilton Depression Scale (HAMD) significantly decreased 1 week after the surgeries. No long-lasting adverse events or complications of the procedures were reported. ${ }^{14,15}$

The glucose metabolism of 6 patients diagnosed with anorexia nervosa and 12 age-matched healthy controls were analyzed using fluorine-18-fluorodeoxyglucose positron emission tomography $\left({ }^{18} \mathrm{~F}-\mathrm{FDG}\right.$-PET). Certain cerebral areas of patients with anorexia nervosa showed hypermetabolism in comparison to healthy controls, namely the frontal lobe, lentiform nucleus, and hippocampus. Bilateral NAc DBS was performed in four of the patients with anorexia nervosa. After the surgical procedure, the cerebral areas with hypermetabolism had a decrease in their metabolism. It was hypothesized that the frontal lobe, the lentiform nucleus, and the hippocampus are responsible for the obsessive symptoms and eating disorders that characterize anorexia nervosa. Nevertheless, larger randomized controlled trials are needed to confirm this evidence. ${ }^{16}$

A Canadian group focused on the subcallosal cingulate (SCC) as a DBS target for the treatment of anorexia nervosa. In their first study, 6 anorexia nervosa patients underwent bilateral SCC DBS (130 Hz; $90 \mu \mathrm{s} ; 3.5 \mathrm{~V})$. At the beginning of the study, the mean age of the patients was 38.3 years, while the average duration of this disease was 18.3 years. A 9-month follow-up after DBS pointed to improvements on the psychiatric condition and quality of life of the patients, with decreases in HAMD (17.8 at baseline versus 10.7 at the end of the study), Beck Depression Inventory (BDI) (38.8 versus 20.2), Y-BOCS (25.0 versus 13.2), and Beck Anxiety Inventory (BAI) (31.2 versus 21.7 ) scores, and an increase from an average of 57.3 at baseline to 65.8 at the end of the study in the Quality of Life Scale (QOLS or Flanagan score). At 
the final follow-up, three patients had gained weight and three remained with the same BMI of the pre-surgery phase. ${ }^{3}$

In the second study of the same Canadian group, the investigation was expanded, enrolling 16 anorexia nervosa patients that were followed for 12 months after SCC DBS $(130 \mathrm{~Hz} ; 90 \mu \mathrm{s} ; 5-6.5 \mathrm{~V})$. The results point to a significant increase in BMI $\left(13.83 \mathrm{~kg} / \mathrm{m}^{2}\right.$ at baseline versus $17.34 \mathrm{~kg} / \mathrm{m}^{2}$ at the final follow-up, $p=0.0009$ ), as well as a significant decrease in depression, obsession, compulsion, and anxiety symptoms after 12 months. These outcomes show that the benefits of DBS can be better evaluated with a longer follow-up period. ${ }^{2}$ Some adverse events, such as pancreatitis, seizure, QT prolongation, hypophosphatemia, refeeding delirium, and worsening of mood, were reported after the procedure. Nevertheless, these events were related to the fragility caused by anorexia nervosa rather than to the DBS procedure. ${ }^{2}$

Deep brain stimulation has also been used in singlepatient studies to treat anorexia nervosa associated with other psychiatric disorders. ${ }^{17-19}$ A 56-year-old female patient diagnosed with recurrent depression and anorexia nervosa in adolescence underwent DBS in the subgenual cingulate area (intermittent stimulation: 2 minutes on, 1 minute off; $5 \mathrm{~mA}$; $91 \mu \mathrm{s}$ ). Three years after the surgery, her BMI increased from 14.1 to 19.1 and the Eating Attitudes Test (EAT-26) score decreased from 40.56 to 1.0. Even after a depressive episode because of the suicide of a friend, the symptoms of the eating disorder have been under control. ${ }^{17}$

A 52-year-old female patient with severe OCD since childhood and several comorbidities such as depression, anorexia nervosa, generalized anxiety disorder, and attention-deficit/hyperactivity disorder underwent bilateral ventral striatum DBS (120 Hz; $120 \mu \mathrm{s} ; 7.5 \mathrm{~V}$ ). Her BMI increased from $18.5 \mathrm{~kg} / \mathrm{m}^{2}$ at baseline to $19.6 \mathrm{~kg} / \mathrm{m}^{2}$ at follow-up. In addition, the patient revealed to be more comfortable with food after implantation. ${ }^{18}$

More recently, a 60-year-old female patient with a diagnosis of childhood onset of anxiety and anorexia nervosa presented with symptoms of anxiety connected to food intake, restricted eating, purging, major depressive disorder leading to suicidal ideations and attempts. After years of psychotherapy, several different classes of medication, electroconvulsive therapy, and commitment to a closed psychiatric ward with no improvement whatsoever, she underwent implantation of two DBS electrodes in the medial forebrain bundle $(130 \mathrm{~Hz} ; 60 \mu \mathrm{s} ; 2.8-3.0 \mathrm{~V}$ ) with excellent results. However, due to neurological adverse events, the patient was subjected to reoperation 2 years after the first surgery. In the second procedure, bilateral electrodes $(130 \mathrm{~Hz} ; 120 \mu \mathrm{s}$; $4.3 \mathrm{~V}$ ) were implanted in the bed nucleus of the stria terminalis (BNST). Although no improvements regarding BMI were observed after the second implantation, her food intake became more stable, the purging episodes disappeared, tube feeding could be discontinued, she was released from the psychiatric ward, and is now living at home with her family. $^{19}$

All the details about the patients, comorbidities, DBS targets, and outcomes after the procedures in the eight studies selected are summarized in -Table 1.

\section{Discussion}

The 29 patients diagnosed with anorexia nervosa that underwent DBS selected in this systematic literature review were female, with mean age of $30.9 \pm 13.1$ years at baseline, ranging from 16 to 60 years old.

The targets for DBS implantation were: SCC, NAc, subgenual cingulate cortex, ventral striatum, medial forebrain bundle and BNST. All these areas and structures participate in the pathological circuit of anorexia nervosa. ${ }^{2,3,14-19}$ Although all the studies selected reported a beneficial effect of DBS in the clinical presentation of anorexia nervosa, it is still not possible to determine which target was the most effective, due to the great diversity of the subjects treated.

Deep brain stimulation increased the BMI in all patients, except one. ${ }^{19}$ Additionally, consequences of the disease such as food aversion and psychiatric comorbidities greatly decreased in all studies after DBS intervention. Improvements were achieved in physical and psychiatric aspects of the subjects that underwent this type of treatment, with few or no longlasting adverse effects resulting from the procedure. $2,3,14-19$

However, the broad and clinical use of DBS for the treatment of anorexia nervosa symptoms cannot be endorsed yet, because of lack of evidence obtained from standardized, systematic, double-blind, placebo-controlled trials. ${ }^{2,3,6,17}$ Nonetheless, the perspective for the near future is optimistic, once consolidated clinical trials with the use of sham stimulation and doubleblind crossover approach, ${ }^{20}$ as well as comparing DBS to clinical therapy, ${ }^{21}$ have been designed.

This systematic literature review had certain limitations due to the small number of studies and patients involved, as well as the lack of standardized inclusion criteria for patients with anorexia nervosa that could benefit from DBS treatment. A well-established definition of anorexia nervosa refractory to clinical treatment is a critical concept that is yet to be determined.

In 2017, a framework was presented to guide researchers through the ethical implications involving the treatment of severe and enduring anorexia nervosa using DBS. It includes steps such as assessing individual needs and possible risks and benefits, considering issues of mental capacity and informed consent, and considering future care after participation in the research. ${ }^{22}$ Similarly, broader frameworks, involving the clinical, psychological, and social aspects of patients diagnosed with anorexia nervosa should be designed to better guide the patient selection process.

Since the factors involved in the pathophysiology of anorexia nervosa are rather complex and multifaceted, the exact neurocircuitry of this disorder has not been completely elucidated yet. ${ }^{10,14}$ To this moment, it has not been possible to isolate one single structure or pathway responsible for triggering the symptoms of the disease. Therefore, a model involving multiple circuits has been indicated as the most plausible explanation for the occurrence of the disease. ${ }^{23}$

Studies conducted to investigate the neurocircuitry of anorexia nervosa often rely on important neuronal targets, whose functions and dysfunctions underly the clinical manifestations of the disease, such as pathologic humor, anxiety, 
Table 1 Clinical profiles, comorbidities, stimulation targets, and outcomes of patients diagnosed with anorexia nervosa that underwent deep brain stimulation (DBS) in eight studies selected in this systematic literature review

\begin{tabular}{|c|c|c|c|c|c|}
\hline $\begin{array}{l}\text { Patients } \\
\text { (n) }\end{array}$ & Clinical profile & Comorbidity & DBS target & Outcome & Reference \\
\hline \multirow[t]{4}{*}{4} & $\begin{array}{l}\text { 1. } 16 \text { years old; female; AN } \\
\text { duration: } 28 \text { months; } \\
\text { amenorrhea duration: } \\
11 \text { months; suspension } \\
\text { from school: } 5 \text { months; BMI } \\
\text { at baseline: } 12.2 \mathrm{~kg} / \mathrm{m}^{2} \text {; } \\
\text { medication: SSRI; } \\
\text { olanzapine }\end{array}$ & OCD & NAC & \multirow[t]{4}{*}{$\begin{array}{l}\text { After a mean follow-up of } \\
38 \text { months - average BMI: } \\
19.6 \mathrm{~kg} / \mathrm{m}^{2} \text { (increased by } \\
65 \% \text { ); Y-BOCS decreased from } \\
29 \text { to } 1.7 ; \text { HAMA decreased } \\
\text { from } 19 \text { to } 2 ; \text { menses } \\
\text { returned within an average } \\
\text { period of } 6.8 \text { months; three } \\
\text { patients returned to school }\end{array}$} & \multirow[t]{4}{*}{14} \\
\hline & $\begin{array}{l}\text { 2. } 16 \text { years old; female; AN } \\
\text { duration: } 18 \text { months; ame- } \\
\text { norrhea duration: } \\
15 \text { months; suspension } \\
\text { from school: } 3 \text { months; BMI } \\
\text { at baseline: } 13.3 \mathrm{~kg} / \mathrm{m}^{2} \text {; } \\
\text { medication: SSRI; } \\
\text { olanzapine }\end{array}$ & OCD & NAC & & \\
\hline & $\begin{array}{l}\text { 3. } 17 \text { years old; female; AN } \\
\text { duration: } 15 \text { months; } \\
\text { amenorrhea duration: } \\
9 \text { months; suspension from } \\
\text { school: } 10 \text { months; BMl at } \\
\text { baseline: } 12 \mathrm{~kg} / \mathrm{m}^{2} \text {; medi- } \\
\text { cation: SSRI; olanzapine }\end{array}$ & GAD & NAC & & \\
\hline & $\begin{array}{l}\text { 4. } 16 \text { years old; female; AN } \\
\text { duration: } 13 \text { months; } \\
\text { amenorrhea duration: } \\
9 \text { months; suspension from } \\
\text { school: } 6 \text { months; BMI at } \\
\text { baseline: } 10 \mathrm{~kg} / \mathrm{m}^{2} \text {; medi- } \\
\text { cation: } \text { SSRI }\end{array}$ & OCD & NAC & & \\
\hline \multirow[t]{2}{*}{2} & $\begin{array}{l}\text { 1. } 28 \text { years old; female; AN } \\
\text { duration: } 2 \text { years; BMl at } \\
\text { baseline: } 13.3 \mathrm{~kg} / \mathrm{m}^{2} \text {; vital } \\
\text { signs at baseline }- \text { tem- } \\
\text { perature: } 35.5^{\circ} \mathrm{C} \text {; heart } \\
\text { rate: } 47 \mathrm{bpm} \text {; blood pres- } \\
\text { sure: } 91 \times 60 \mathrm{~mm} \mathrm{Hg} \\
\text { HAMD: } 24 \text {; HAMA: } 35\end{array}$ & Not reported & NAC & $\begin{array}{l}1 \text { year after surgery - BMI: } 18 \\
\mathrm{~kg} / \mathrm{m}^{2} \text {; temperature: } 36.4^{\circ} \mathrm{C} \text {; } \\
\text { heart rate: } 71 \text { bpm; blood } \\
\text { pressure: } 107 \times 71 \mathrm{~mm} \mathrm{Hg} \text {; } \\
\text { HAMD: 9; HAMA: } 8\end{array}$ & \multirow[t]{2}{*}{15} \\
\hline & $\begin{array}{l}\text { 2. } 18 \text { years old; female; AN } \\
\text { duration: } 3 \text { years; BMl at } \\
\text { baseline: } 12.9 \mathrm{~kg} / \mathrm{m}^{2} \text {; vital } \\
\text { signs at baseline }- \\
\text { temperature: } 35.6^{\circ} \mathrm{C} \text {; heart } \\
\text { rate: } 48 \text { bpm; blood } \\
\text { pressure: } 82 \times 60 \mathrm{~mm} \mathrm{Hg} \text {; } \\
\text { HAMD: } 20 \text {; HAMA: } 24\end{array}$ & Not reported & NAC & $\begin{array}{l}1 \text { year after surgery-BMl: } \\
20.8 \mathrm{~kg} / \mathrm{m}^{2} \text {; temperature: } \\
36.3^{\circ} \mathrm{C} \text {; heart rate: } 69 \mathrm{bpm} \text {; } \\
\text { blood pressure: } 96 \times 66 \mathrm{~mm} \\
\text { Hg; HAMD: 9; HAMA: } 7\end{array}$ & \\
\hline \multirow[t]{2}{*}{4} & $\begin{array}{l}\text { 1. } 18 \text { years old; female; AN } \\
\text { duration: } 13 \text { months; } \\
\text { amenorrhea duration: } \\
4 \text { months; suspension from } \\
\text { school: } 2 \text { months; BMI at } \\
\text { baseline: } 11.8 \mathrm{~kg} / \mathrm{m}^{2} ; \\
\text { medication: } \mathrm{SSRI}\end{array}$ & Not reported & NAC & $\begin{array}{l}1 \text { month after surgery-BMI: } \\
17.9 \mathrm{~kg} / \mathrm{m}^{2} \text {; no medication }\end{array}$ & \multirow[t]{2}{*}{16} \\
\hline & $\begin{array}{l}\text { 2. } 16 \text { years old; female; AN } \\
\text { duration: } 28 \text { months; ame- } \\
\text { norrhea duration: } \\
11 \text { months; suspension } \\
\text { from school: } 5 \text { months; BMI } \\
\text { at baseline: } 11.2 \mathrm{~kg} / \mathrm{m}^{2} \text {; } \\
\text { medication: SSRI, } \\
\text { olanzapine }\end{array}$ & Not reported & NAC & $\begin{array}{l}1 \text { month after surgery - BMI: } \\
13.1 \mathrm{~kg} / \mathrm{m}^{2} ; \text { no medication }\end{array}$ & \\
\hline
\end{tabular}


Table 1 (Continued)

\begin{tabular}{|c|c|c|c|c|c|}
\hline Patients & Clinical profile & Comorbidity & DBS target & Outcome & Reference \\
\hline & $\begin{array}{l}\text { 3. } 16 \text { years old; female; AN } \\
\text { duration: } 18 \text { months; ame- } \\
\text { norrhea duration: } \\
15 \text { months; suspension } \\
\text { from school: } 3 \text { months; BMI } \\
\text { at baseline: } 13.3 \mathrm{~kg} / \mathrm{m}^{2} \text {; } \\
\text { medication: } S S R I, \\
\text { olanzapine }\end{array}$ & Not reported & NAC & $\begin{array}{l}1 \text { month after surgery-BMI: } \\
14.5 \mathrm{~kg} / \mathrm{m}^{2} \text {; no medication }\end{array}$ & \\
\hline & $\begin{array}{l}\text { 4. } 16 \text { years old; female; AN } \\
\text { duration: } 42 \text { months; ame- } \\
\text { norrhea duration: } \\
24 \text { months; suspension } \\
\text { from school: } 12 \text { months; } \\
\text { BMI at baseline: } 12.2 \mathrm{~kg} / \mathrm{m}^{2} \text {; } \\
\text { medication: } S S R I\end{array}$ & Not reported & NAC & $\begin{array}{l}1 \text { month after surgery-BMI: } \\
17.1 \mathrm{~kg} / \mathrm{m}^{2} \text {; no medication }\end{array}$ & \\
\hline \multirow[t]{14}{*}{16} & $\begin{array}{l}\text { 1. } 24 \text { years old; female; AN } \\
\text { duration: } 10 \text { years; lowest } \\
\text { BMI: } 11 \mathrm{~kg} / \mathrm{m}^{2}\end{array}$ & MDD; anxiety & SCC & \multirow{14}{*}{$\begin{array}{l}\text { Significant increase in BMI } \\
(p=0.0009) \text { and QOLS } \\
(p=0.021) \text {; significant } \\
\text { decrease in Y-BOCS } \\
(p=0.023), \text { HAMD } \\
(p=0.00015), \text { BDI } \\
(p=0.0022), \text { BAI } \\
(p=0.035), \text { DERS } \\
(p=0.019), \text { YBC-EDS-p } \\
(p=0.0025), \text { and YBC-EDS-r } \\
(p=0.0013) \text { scores }\end{array}$} & \multirow[t]{14}{*}{2,3} \\
\hline & $\begin{array}{l}\text { 2. } 38 \text { years old; female; AN } \\
\text { duration: } 21 \text { years; lowest } \\
\text { BMI: } 11.9 \mathrm{~kg} / \mathrm{m}^{2}\end{array}$ & $\begin{array}{l}\text { MDD; PTSD; } \\
\text { SUD; OCD }\end{array}$ & SCC & & \\
\hline & $\begin{array}{l}\text { 3. } 35 \text { years old; female; AN } \\
\text { duration: } 15 \text { years; lowest } \\
\text { BMI: } 12.4 \mathrm{~kg} / \mathrm{m}^{2}\end{array}$ & MDD; PTSD & SCC & & \\
\hline & $\begin{array}{l}\text { 4. } 40 \text { years old; female; AN } \\
\text { duration: } 10 \text { years; lowest } \\
\text { BMI: } 13.1 \mathrm{~kg} / \mathrm{m}^{2}\end{array}$ & MDD; PTSD & SCC & & \\
\hline & $\begin{array}{l}\text { 5. } 35 \text { years old female; AN } \\
\text { duration: } 19 \text { years; lowest } \\
\text { BMI: } 13.5 \mathrm{~kg} / \mathrm{m}^{2}\end{array}$ & $\begin{array}{l}\text { MDD; PTSD; } \\
\text { GAD }\end{array}$ & SCC & & \\
\hline & $\begin{array}{l}\text { 6. } 57 \text { years old; female; AN } \\
\text { duration: } 27 \text { years; lowest } \\
\text { BMI: } 13.0 \mathrm{~kg} / \mathrm{m}^{2}\end{array}$ & None & SCC & & \\
\hline & $\begin{array}{l}\text { 7. } 21 \text { years old; female; AN } \\
\text { duration: } 9 \text { years; lowest } \\
\text { BMI: } 11.2 \mathrm{~kg} / \mathrm{m}^{2}\end{array}$ & $\begin{array}{l}\text { MDD; OCD; } \\
\text { GAD; BPD }\end{array}$ & SCC & & \\
\hline & $\begin{array}{l}\text { 8. } 32 \text { years old; female; AN } \\
\text { duration: } 19 \text { years; lowest } \\
\text { BMI: } 12.9 \mathrm{~kg} / \mathrm{m}^{2}\end{array}$ & MDD; PTSD & SCC & & \\
\hline & $\begin{array}{l}\text { 9. } 26 \text { years old; female; AN } \\
\text { duration: } 14 \text { years; lowest } \\
\text { BMI: } 14.8 \mathrm{~kg} / \mathrm{m}^{2}\end{array}$ & PTSD & SCC & & \\
\hline & $\begin{array}{l}\text { 10. } 30 \text { years old; female; AN } \\
\text { duration: } 19 \text { years; lowest } \\
\text { BMI: } 10.6 \mathrm{~kg} / \mathrm{m}^{2}\end{array}$ & MDD; OCD & SCC & & \\
\hline & $\begin{array}{l}\text { 11. } 39 \text { years old; female; AN } \\
\text { duration: } 24 \text { years; lowest } \\
\text { BMl: } 10.3 \mathrm{~kg} / \mathrm{m}^{2}\end{array}$ & $\begin{array}{l}\text { MDD, PTSD; } \\
\text { OCD }\end{array}$ & SCC & & \\
\hline & $\begin{array}{l}\text { 12. } 39 \text { years old female; AN } \\
\text { duration: } 29 \text { years; lowest } \\
\text { BMI: } 7.2 \mathrm{~kg} / \mathrm{m}^{2}\end{array}$ & PTSD; GAD & SCC & & \\
\hline & $\begin{array}{l}\text { 13. } 32 \text { years old; female; AN } \\
\text { duration: } 20 \text { years; lowest } \\
\text { BMI: } 11.4 \mathrm{~kg} / \mathrm{m}^{2}\end{array}$ & $\begin{array}{l}\text { MDD; PTSD; } \\
\text { OCD }\end{array}$ & SCC & & \\
\hline & $\begin{array}{l}\text { 14. } 34 \text { years old; female; AN } \\
\text { duration: } 19 \text { years; lowest } \\
\text { BMI: } 15.1 \mathrm{~kg} / \mathrm{m}^{2}\end{array}$ & $\begin{array}{l}\text { MDD; anxiety; } \\
\text { PTSD }\end{array}$ & SCC & & \\
\hline
\end{tabular}


Table 1 (Continued)

\begin{tabular}{|c|c|c|c|c|c|}
\hline $\begin{array}{l}\text { Patients } \\
\text { (n) }\end{array}$ & Clinical profile & Comorbidity & DBS target & Outcome & Reference \\
\hline & $\begin{array}{l}\text { 15. } 34 \text { years old; female; AN } \\
\text { duration: } 21 \text { years; lowest } \\
\text { BMl: } 10 \mathrm{~kg} / \mathrm{m}^{2}\end{array}$ & $\begin{array}{l}\text { MDD; OCD; } \\
\text { BPD }\end{array}$ & SCC & & \\
\hline & $\begin{array}{l}\text { 16. } 34 \text { years old; female; AN } \\
\text { duration: } 11 \text { years; lowest } \\
\text { BMI: } 13.7 \mathrm{~kg} / \mathrm{m}^{2}\end{array}$ & None & SCC & & \\
\hline 1 & $\begin{array}{l}56 \text { years old; female; AN } \\
\text { duration: } 35 \text { years; BMI at } \\
\text { baseline: } 14.1 \mathrm{~kg} / \mathrm{m}^{2} ; \\
\text { relapses of AN precipitated by } \\
\text { depression episodes; } \\
\text { EAT-26 at baseline: } 40.56\end{array}$ & $\begin{array}{l}\text { Severe } \\
\text { refractory } \\
\text { depression }\end{array}$ & $\begin{array}{l}\text { Subgenual } \\
\text { cingulate cortex }\end{array}$ & $\begin{array}{l}\text { Remission of AN symptoms; } \\
2 \text { years after surgery - BMI: } \\
19.1 \mathrm{~kg} / \mathrm{m}^{2} ; 3 \text { years after } \\
\text { surgery - EAT-26: } 1.0 \text {; medi- } \\
\text { cation after DBS: escitalo- } \\
\text { pram, trazodone, triptophan, } \\
\text { clonazepam }\end{array}$ & 17 \\
\hline 1 & $\begin{array}{l}52 \text { years old; female; BMI at } \\
\text { baseline: } 18.5 \mathrm{~kg} / \mathrm{m}^{2} ; \text { long- } \\
\text { term concern over weight } \\
\text { gain; avoided social events } \\
\text { involving food; restricted } \\
\text { portion size }\end{array}$ & $\begin{array}{l}\text { MDD; OCD; } \\
\text { GAD; ADHD }\end{array}$ & Ventral striatum & $\begin{array}{l}\text { After DBS: patient more com- } \\
\text { fortable with food, eating } \\
\text { higher amounts and variety, } \\
\text { and accepting going out to eat; } \\
\text { BMl at follow up: } 19.6 \mathrm{~kg} / \mathrm{m}^{2}\end{array}$ & 18 \\
\hline 1 & $\begin{array}{l}60 \text { years old; female; BMI at } \\
\text { baseline: } 16.6 \mathrm{~kg} / \mathrm{m}^{2} \text {; child- } \\
\text { hood onset anorexia nervosa; } \\
\text { committed to psychiatric } \\
\text { ward; MADRS: 43, HAMD: } \\
\text { 22, HAMA: } 22\end{array}$ & MDD; anxiety & $\begin{array}{l}\text { First procedure: electrode } \\
\text { implantation in medial } \\
\text { forebrain bundle, } \\
\text { with collateral effect: } \\
\text { blurred vision; second } \\
\text { procedure: electrode } \\
\text { implantation in BNST }\end{array}$ & $\begin{array}{l}9 \text { months after second pro- } \\
\text { cedure-released from psy- } \\
\text { chiatric ward; } 12 \text { months } \\
\text { after second procedure- } \\
\text { depression and anxiety scores } \\
\text { improved dramatically, } \\
\text { MADRS: } 13 \text {; HAMD: 6; HAMA: } \\
\text { 5; neither procedure had sig- } \\
\text { nificant impact on BMI; anxi- } \\
\text { ety involving food } \\
\text { disappeared; food intake } \\
\text { became more stable; tube } \\
\text { feeding was discontinued }\end{array}$ & 19 \\
\hline
\end{tabular}

Abbreviations: ADHD, attention deficit/hyperactivity disorder; AN, anorexia nervosa; BAI, Beck Anxiety Inventory; BDI, Beck Depression Inventory; $\mathrm{BMI}$, body mass index; BNST, bed nucleus of the stria terminalis; BPD, borderline personality disorder; bpm, beats per minute; DERS, Dysfunction in Emotional Regulation Scale; EAT-26, Eating Attitudes Test; GAD, generalized anxiety disorder; HAMA, Hamilton Rating Scale for Anxiety; HAMD, Hamilton Depression Scale; MADRS, Montgomery-Åsberg Depression Rating; MDD, major depressive disorder; NAc: nucleus accumbens; OCD, obsessive-compulsive disorder; PTSD, posttraumatic stress disorder; QOLS, Quality of Life Score; SCC, subcallosal cingulate; SSRI, serotonin selective reuptake inhibitors; SUD, substance use disorder; YBC-EDS-p, Yale-Brown-Cornell Eating Disorders Scale, purging; YBC-EDS-r, Yale-Brown-Cornell Eating Disorders Scale, restriction; Y-BOCS, Yale-Brown Obsessive Compulsive Scale.

eating disorders, distorted body perception, inhibition, and alexithymia. ${ }^{24,25}$ For that matter, neuroimaging techniques such as ${ }^{18}$ F-FDG-PET, single-photon emission computed tomography (SPECT), and functional magnetic resonance imaging (fMRI) have been of great assistance, once functional and structural differences are found between the brains of anorexic patients and healthy individuals. ${ }^{26}$

Most of these differences can be observed in the limbic lobe, in the pre-frontal cortex, and in the cingulate cortex, areas responsible for the management of emotions and behavior. ${ }^{11,27}$ For instance, the components of the reward system, especially NAc, which belong to the cortex-striatum-thalamus-cortical circuit, are dysfunctional in anorexic individuals. Such dysfunction explains why food, naturally a primary reinforcer, is likely to trigger an appetite-aversion response in anorexia nervosa patients. ${ }^{14,25}$

Also, anorexic patients are prone to consider themselves heavier and larger compared with other people. ${ }^{1}$ This pathological feature may be explained by the reduced activity of the parietal cortex in anorexic patients, as shown by SPECT, positron emission tomography (PET), and fMRI. ${ }^{28}$ The parietal cortex is responsible for the visuospatial abilities and the construction of body image; therefore, its hypoactivity contributes to the distorted self-perception in anorexia nervosa patients. ${ }^{14}$

Another distinctive finding in patients with anorexia nervosa is mood and affective disorders, partly derived from dysfunctional actions of the ventromedial prefrontal cortex and orbitofrontal cortex, which stimulate non-adaptive behaviors, such as self-starvation and self-harm, in these individuals. ${ }^{29}$ In addition to this, fMRI studies have revealed hypoactivity in the ventral striatum, supplementary motor area, and frontal-striatal circuits in anorexic patients, which may justify the low levels of cognitive flexibility of these individuals. Moreover, the subcallosal and subgenual cingulate cortex are involved in major depressive disorder, OCD, and abnormal mood seen in anorexia nervosa patients. ${ }^{28,30}$

Positron emission tomography/SPECT studies have also demonstrated the presence of abnormalities in the dopamine 
and serotonin systems in anorexic patients. It seems that anxiety manifestations, behavioral inhibition, and body image distortions are associated with alterations in 5-HT1A and 5-HT1B receptors, as well as in serotonin transporters in limbic and cortical structures. Dopamine is pathologically increased in the brain of anorexic patients, leading to anxiety symptoms, which are alleviated through starvation. ${ }^{14}$

\section{Conclusion}

Anorexia nervosa is a debilitating and, in some instances, lethal disorder. Deep brain stimulation has been used experimentally in multiple targets of the neurocircuitry of anorexia nervosa, such as NAc, SCC, striatum, subgenual cingulate, and BNST. The results have shown that DBS is a safe and effective method in the regression of the symptoms of this disease. However, it is important to emphasize that DBS is still an experimental approach for the treatment of anorexia nervosa. Therefore, a larger number of studies with a broader scope is needed in order for the clinical use of DBS can be recommended.

Conflicts of Interest

The authors have no conflicts of interest to declare.

\section{References}

1 American Psychiatric Association. Diagnostic and Statistical Manual of Mental Disorders (5th ed.). Washington, DC: APA; 2013

2 Lipsman N, Lam E, Volpini M, et al. Deep brain stimulation of the subcallosal cingulate for treatment-refractory anorexia nervosa: 1 year follow-up of an open-label trial. Lancet Psychiatry 2017;4 (04):285-294. Doi: 10.1016/S2215-0366(17)30076-7

3 Lipsman N, Woodside DB, Giacobbe P, et al. Subcallosal cingulate deep brain stimulation for treatment-refractory anorexia nervosa: a phase 1 pilot trial. Lancet 2013;381(9875):1361-1370. Doi: 10.1016/S0140-6736(12)62188-6

4 Wood L, Al-Khairulla H, Lask B. Group cognitive remediation therapy for adolescents with anorexia nervosa. Clin Child Psychol Psychiatry 2011;16(02):225-231. Doi: 10.1177/135910451140 4750

5 Bartsch C, Kuhn J. Tiefe Hirnstimulation bei Sucht, Anorexie und Zwang. Rationale, klinische Ergebnisse und ethische Implikationen. Nervenarzt 2014;85(02):162-168

6 Prinz P, Stengel A. Deep brain stimulation-possible treatment strategy for pathologically altered body weight? Brain Sci 2018;8 (01):1-15. Doi: 10.3390/brainsci8010019

7 Norrington A, Stanley R, Tremlett M, Birrell G. Medical management of acute severe anorexia nervosa. Arch Dis Child Educ Pract Ed 2012;97(02):48-54. Doi: 10.1136/adc.2010.199885

8 Oudijn MS, Storosum JG, Nelis E, Denys D. Is deep brain stimulation a treatment option for anorexia nervosa? BMC Psychiatry 2013;13:277. Doi: 10.1186/1471-244X-13-277

9 Arcelus J, Mitchell AJ, Wales J, Nielsen S. Mortality rates in patients with anorexia nervosa and other eating disorders. A meta-analysis of 36 studies. Arch Gen Psychiatry 2011;68(07):724-731. Doi: 10.1001/archgenpsychiatry.2011.74

10 Redgrave GW, Bakker A, Bello NT, et al. Differential brain activation in anorexia nervosa to Fat and Thin words during a Stroop task. Neuroreport 2008;19(12):1181-1185. Doi: 10.1097/WNR.0 b013e32830a70f2

11 Sun B, Li D, Liu W, Zhan S, Pan Y, Zhang X. Surgical treatments for anorexia nervosa. In: Sun B, Salles A, editors. Neurosurgical Treatments for Psychiatric Disorders. Dordrecht: Springer; 2015:175-187
12 Pietrini F, Castellini G, Ricca V, Polito C, Pupi A, Faravelli C. Functional neuroimaging in anorexia nervosa: a clinical approach. Eur Psychiatry 2011;26(03):176-182

13 Liberati A, Altman DG, Tetzlaff J, et al. The PRISMA statement for reporting systematic reviews and meta-analyses of studies that evaluate healthcare interventions: explanation and elaboration. BMJ 2009;339:b2700. Doi: 10.1136/bmj.b2700

$14 \mathrm{Wu} \mathrm{H}$, Van Dyck-Lippens PJ, Santegoeds R, et al. Deep-brain stimulation for anorexia nervosa. World Neurosurg 2013;80(3-4):29. e1-29.e10

15 Wang J, Chang C, Geng N, Wang X, Gao G. Treatment of intractable anorexia nervosa with inactivation of the nucleus accumbens using stereotactic surgery. Stereotact Funct Neurosurg 2013;91 (06):364-372. Doi: 10.1159/000348278

16 Zhang HW, Li DY, Zhao J, Guan YH, Sun BM, Zuo CT. Metabolic imaging of deep brain stimulation in anorexia nervosa: a 18F-FDG PET/CT study. Clin Nucl Med 2013;38(12):943-948. Doi: 10.1097/ RLU.0000000000000261

17 Israël M, Steiger H, Kolivakis T, McGregor L, Sadikot AF. Deep brain stimulation in the subgenual cingulate cortex for an intractable eating disorder. Biol Psychiatry 2010;67(09):e53-e54. Doi: 10.1016 /j.biopsych.2009.11.016

18 McLaughlin NCR, Didie ER, Machado AG, Haber SN, Eskandar EN, Greenberg BD. Improvements in anorexia symptoms after deep brain stimulation for intractable obsessive-compulsive disorder. Biol Psychiatry 2013;73(09):e29-e31. Doi: 10.1016/j.biopsych.2012.09.015

19 Blomstedt P, Naesström M, Bodlund O. Deep brain stimulation in the bed nucleus of the stria terminalis and medial forebrain bundle in a patient with major depressive disorder and anorexia nervosa. Clin Case Rep 2017;5(05):679-684. Doi: 10.1002/ccr3.856

20 Martínez GV. Deep brain stimulation for patients with chronic, severe and resistant anorexia nervosa. Barcelona, Spain, 2017. (ongoing clinical trial). Available at: https://clinicaltrials.gov/ct2/ show/NCT03168893. Access in: July 8, 2018

21 Guodong G. Deep brain stimulation of nucleus accumbens to treat severe anorexia nervosa. Tangdu Hospital, Shaanxi, China, 2015. (ongoing clinical trial). Available at: https://clinicaltrials.gov/ct2/ show/NCT02593695. Access in: July 8, 2018

22 Park RJ, Singh I, Pike AC, Tan JOA. Deep brain stimulation in anorexia nervosa: hope for the hopeless or exploitation of the vulnerable? The Oxford Neuroethics Gold Standard Framework. Front Psychiatry 2017;8:44. Doi: 10.3389/fpsyt.2017.00044

23 Lozano AM, Lipsman N. Probing and regulating dysfunctional circuits using deep brain stimulation. Neuron 2013;77(03): 406-424. Doi: 10.1016/j.neuron.2013.01.020

24 Luyten L, Casteels C, Vansteenwegen D, et al. Micro-positron emission tomography imaging of rat brain metabolism during expression of contextual conditioning. J Neurosci 2012;32(01): 254-263. Doi: 10.1523/JNEUROSCI.3701-11.2012

25 Kaye WH, Wagner A, Fudge JL, Paulus M. Neurocircuity of eating disorders. Curr Top Behav Neurosci 2011;6:37-57. Doi: 10.1007/ 7854_2010_85

26 Kaye WH, Fudge JL, Paulus M. New insights into symptoms and neurocircuit function of anorexia nervosa. Nat Rev Neurosci 2009; 10(08):573-584. Doi: 10.1038/nrn2682

27 Winston AP. The clinical biochemistry of anorexia nervosa. Ann Clin Biochem 2012;49(Pt 2):132-143. Doi: 10.1258/acb.2011.011185

28 van Kuyck K, Gérard N, Van Laere K, et al. Towards a neurocircuitry in anorexia nervosa: evidence from functional neuroimaging studies. J Psychiatr Res 2009;43(14):1133-1145. Doi: 10.1016/j. jpsychires.2009.04.005

29 Brockmeyer T, Friederich HC, Schmidt U. Advances in the treatment of anorexia nervosa: a review of established and emerging interventions. Psychol Med 2018;48(08):1228-1256. Doi: 10.1017/ S0033291717002604

30 Friederich HC, Wu M, Simon JJ, Herzog W. Neurocircuit function in eating disorders. Int J Eat Disord 2013;46(05):425-432. Doi: 10.1002/eat.22099 